\title{
The Establishment and Management of the Archives of Green Food
}

\author{
Chong Zhang*
}

North West University of Politics and Law, P.R. China

\begin{abstract}
The development of green food production, establishment and management of collecting and sorting documentary materials has been put on the agenda. Vigorously strengthen the production bases of green food, the producers of green food, wholesale markets of green food, distribution entities of green food, sales units of green food and supervision and management, establishing the certificate records of quality and records of supervision, strengthen the quality and safety responsibility consciousness of the agricultural producers will enhance the certification of credibility and competitiveness of the products.
\end{abstract}

Keywords: Green food, establishments, management, archives of green food.

\section{INTRODUCTION}

Since 1980s, the green food industry has been gradually developing in Europe and the United States under the green wave, and begun to transform to green and ecological agriculture from the traditional and conventional agriculture. In USA, Italy, Germany and Holland, respectively 77\%, 94\%, $82 \%$ and $67 \%$ of consumers would take the green factors into consideration (Xu, 2001), and the enterprise's green image is influencing shopping desire. At present, the green food demand is much more than its supply in many developed countries.

In China, with a series of food safety crisis in recent years - melamine, drainage oil, clenbuterol, tony red and other local events not reported, the food safety is becoming a hot concerned focus, and the green food industry was initiated to meet the green food demand. Although the green food prices are often 1.3-3.0 times higher than ordinary food, its sales still increase stably and markedly, especially in the coastal econ my-developed cities [1].

With the economic development and improvement of people's living standards, people pay more and more attention to food quality safety, and China's green food industry has experienced rapid development. Heilongjiang Province is one of the provinces with the highest rate of development of green food industry in China, and also the country's largest standardization production base of green food. The production capacity of green food in Heilongjiang Province is very powerful, but all products produced by the certified green food enterprises at present are not all green food. We redefine "green food enterprises" and expound the meaning of "greenification" [2,3] of food processing industry. Taking the case of Heilongjiang Province, we give an overview of green food enterprises in Heilongjiang Province, and study the degree of "greenification" of food processing

*Address correspondence to this author at the NorthWest University of Politics and Law, P.R. China; Tel: +358-6-3247476; Fax: +358-6-3247457; E-mail: hunter2011@foxmail.com industry in Heilongiiang Province, through the case study of the related enterprises. And we put forth the recommendations for promoting "greenification" of food processing industry in Heilongiiang Province.

Green food means safe and high-quality esculent agricultural and processed products without being polluted, growing in excellent environment, produced according to regularized technological speculations, with quality controlled through the whole processing. On the basis of foreign standard of green food and situation of China, the China Green Food Development Center divides green food into two categories, namely AA grade green food and A grade green food. The origin environment, production process, product quality, packaging, transport and other conditions of the reporting enterprises must comply with the standard of green food, and go through the test of corresponding agencies, to obtain the right to use the green food indication [4].

\section{THE GENERAL SITUATION OF THE GREEN FOOD INDUSTRY AND DOMESTIC GREEN FOOD MARKET}

\subsection{Domestic Green Food Market of Green Food}

Since 1990s, the green food industry in China has a certain market share since, with upgrading industry level, growing brand influence, and more and more obviously comprehensive benefits. According to the investigation in large and medium-sized cities, the level of awareness of green food brand has been more than $70 \%$, which has become the favorite brand. In recent years, the pass rate of green food products remains at a high level. In 2010, the pass rate of green food products has reached $98.9 \%$ in the sample $[5,6]$.

Next, we will briefly introduce the current situation of green food industry, through development momentum, the output of major products and so on.

China's green food industry has rapid growth. Green food enterprises, output of green food, sales of green food, amount of exports consistently have a rising trend, and the 
average annual growth rate of the indicators are $17.98 \%$, $21.34 \%, 20.36 \%, 39.56 \%$ respectively [5].

We can get that in 2007 the planting area detected by relevant agency remains about 24000 acres. Green food production increases year by year, and it means that the effectiveness of green food production is improving. At the same time, we can continue to carry out green food technology introduction, $\mathrm{R} \& \mathrm{D}$, and bring more beneficial impact on green food development by technological progress. It can also be seen the green food market is in great demand. However, the survey also shows that, some consumers have little knowledge about green food, and the idea of green food need to be promoted further.

\subsection{Main Products of Green Food}

Kinds of green food together with output are the important indicator to judge the level of development and structure of green food. According to the product categories, green food can be divided into agricultural products, livestock products. Aquatic products, beverages and other products, and the output of these five kinds of green food fluctuate every year. Take 2011 as an example, agricultural products and processed products has an absolute dominance, about $69.97 \%$ [7].

In terms of output, vegetables, rice and fruit are the top three, and the highest output of vegetables is 14241 thousand tons. The differences of output of various kinds of green food in fact reflects the plant area size of green food, at the same time it also describes the characteristics of green agriculture in China, which requires more labor than others. In the term of resources density, the primary industry of green food is labor-intensive industry, and then capital-intensive industry (including manufacture industry of green food, and technology, detection and management from tertiary industry are technology-intensive. Multiplicity and composite of green food structure make the interaction more complex internally, while it agrees with the fluctuation of national economy structure.

\section{RESULTS AND DISCUSSION}

The development of green food production, establishment and management of collecting and sorting documentary materials has been put on the agenda. Vigorously strengthen the production bases of green food, the producers of green food, wholesale markets of green food, distribution entities of green food, sales units of green food and supervision and management, establishing the certificate records of quality and records of supervision, strengthen the quality and safety responsibility consciousness of the agricultural producers will enhance the certification of credibility and competitiveness of the products.

\subsection{Documentary Materials of Production Base}

It mainly includes applications, inspection reports, evaluation reports, sketches, instructions, and certifications and so on. Various kinds of documentary materials like reports, applications, production projects of green food, product test products and some materials related to the management of the green food which formed on the process of ap- plying using "green food". Technical documentary materials such as drawing, photographs, tabulated, text materials which are generated in the process of cultivation and management of the green food, seeds processing, seeding way, fertilizer using, pest control and prevention, determination of pesticide residue and agriculture harvest. And some materials formed in the course of product packaging, products storage and products selling.

\begin{tabular}{|c|c|c|c|}
\hline Ceagry & Nuler & fied (10 tant) & Ploptate (6) \\
\hline 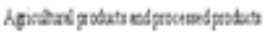 & $117 \%$ & & 69 \\
\hline Wext & 100 & a1 26 & 605 \\
\hline Sitt & 233 & $1 \% 99$ & 148 \\
\hline $\mathrm{Com}$ & ut & $100 t$ & 128 \\
\hline Sogten & 34 & 1235 & 181 \\
\hline Ealli ugrath ol nd teprodats & 30 & 1323 & 202 \\
\hline Vegabler & exs & $14 \times[3$ & 32 \\
\hline Fothes & & toen & 114 \\
\hline inut poseserg pobats & & 458 & 221 \\
\hline Whatrou ed rid rugtêls & at & joll & 242 \\
\hline 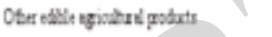 & \$9 & sos: & 415 \\
\hline Livetak edpolity podsts & 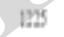 & & $7 x$ \\
\hline fak & 117 & 2015 & 070 \\
\hline Ber & \$4 & $s t 3$ & 0.50 \\
\hline Othrate & 43 & 2573 & 263 \\
\hline $3 \%$ & 31 & 135 & 19 \\
\hline wa & 13 & 6364 & 126 \\
\hline Ben poubcts & 9 & ost3 & 0.20 \\
\hline Agxacpoduts & 40 & & 39? \\
\hline kpquagotusts & 44 & 2412 & 270 \\
\hline Apatepatast & \# & $7 n$ & 122 \\
\hline Bvoreprobts & 171 & & 1017 \\
\hline int ed regable jate ed berng & $n$ & 1971 & 0.58 \\
\hline Pfandrt & 305 & 517 & 503 \\
\hline Spest & is & 107 & t11 \\
\hline Bet & 19 & 2010 & 095 \\
\hline Wis & in & $69 ?$ & 105 \\
\hline Otre dels & 24 & 1998 & 147 \\
\hline Olar padxts & 156 & 289 & 365 \\
\hline
\end{tabular}

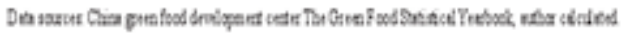

Fig. (1). The survey result of sample.

\subsection{Documentary Materials of the Producers}

Establish the unified The Farmers Archivers System and drawing the base distribution maps and plot distribution maps and give them unified taxation code. The files of the farmers should including the name of the land, the number of the land, the name of the farmers, the crop strains and the planting areas. Management records of the field production should be established and the farmers should have information of the production. The management records of the field production should be filled in by farmers. Contents of it consist of numbers of the land, planter of the land, the name of the crop, crop strains, planting areas, sowing time, soil cultivation and soil fertilization, the prevention and controlling situation of the disease pest and weed, storage records, selling records and so on. Management records of the field pro- 
duction should be submitted within 10 days to base to place on file, and it should be preserved completely for 3 months.

\subsection{Documentary Materials of the Wholesome Market}

Establish the supervision and inspection system and do market supervision and inspection and spot test. It is mainly includes some documentary materials such as records, registration, statistics, files which were produced in the course of doing pesticide residue test of the green food, research on the market and packaging of the green food and wholesome and trading of the green food.

\subsection{Documentary Materials of Delivery}

Establish specific providing base for agricultural products, implement allocation and service of the agricultural products. It mainly includes some documentary materials such as reports, charts, brief introduction, a legal person business license, pollution free certificates, and place of production, distribution entities and suppliers of the green food which were generated in the process of approval access of the green food distribution entities.

\subsection{Documentary Materials of the Selling Records}

It mainly includes documentary materials like application for sales of the green food, the purchase and sale contract of the products, the Enterprise legal person business license, certificates of green food logo, trademark, registration and other documents material of suppliers.

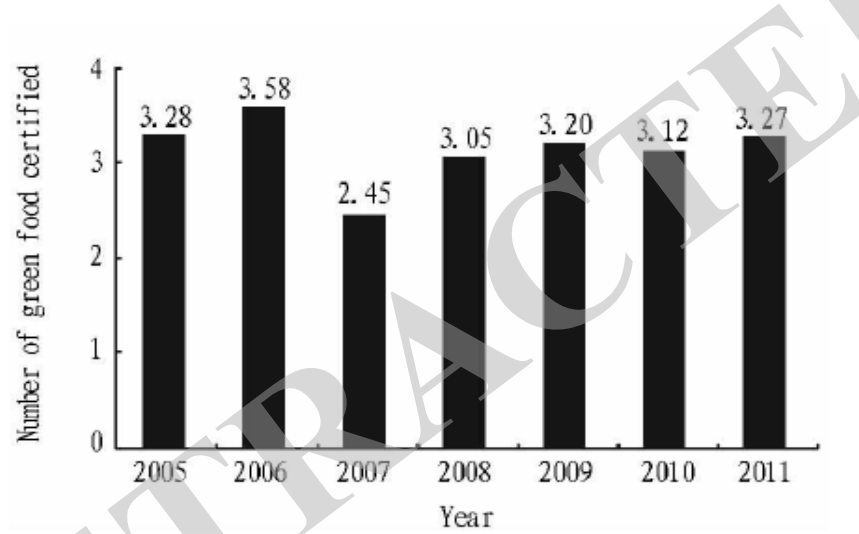

Fig. (2). The number of green food certified.

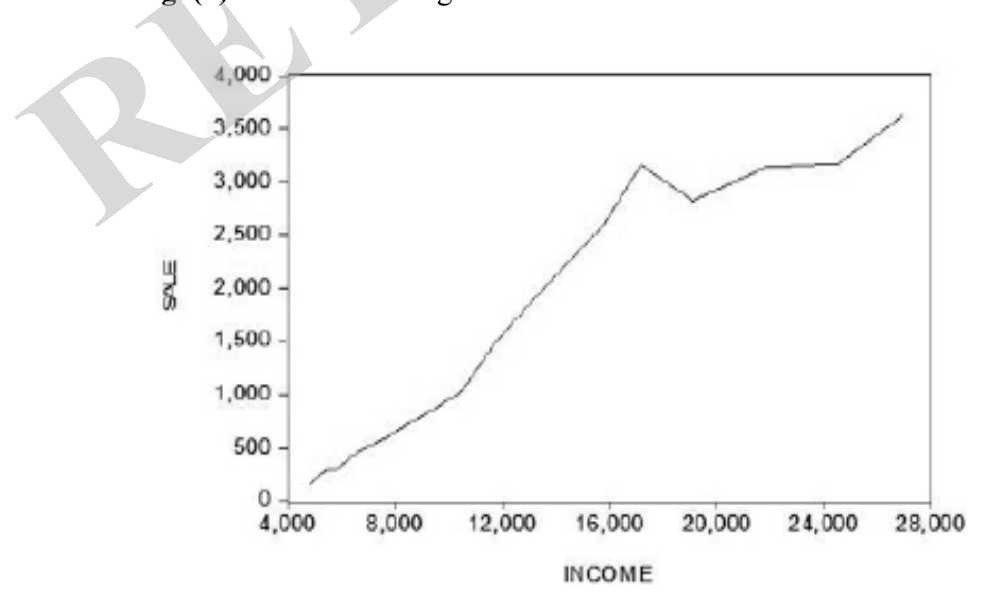

Fig. (3). China Urban residents' disposable income per capita (INCOME) and green food sales.

\section{THE SORTING AND PRESERVING OF THE DOCUMENTARY MATERIALS OF THE GREEN FOOD}

\subsection{Sorting of the Documentary Materials}

It generally includes classification, binding, establish the retention period, arrangement, cataloguing, packing, arrangement on the shelf, etc. It can be divided into the class of general management, such as, the requests from the superior, planning, projects, summary, regulations, systems, execute solutions, articles of the association of the green food, etc. And the class of the operation, such as, the certification materials of the standard production base, filing management table, records of the temperature and humidity, trade registration, medications conditions, fertilization conditions, field management conditions, production status and environment condition detection of the green food, etc.

\subsection{The Preserving of the Documentary Materials}

The documentary materials always were preserved by the department which established them after the documentary materials were sorted out. The requirements of the preservation including fire prevention, water proof, damp proof, mold prevention, insect prevention, rat proof, prevention of thievery, light proof, etc. so that it will be convenient for the future query. Although the paper documentary materials are significant, but at the same time, the computerization and networking management of the documentary materials it also needed to advocate.

\section{THE EFFECT OF THE DOCUMENTARY MATE- RIALS OF THE GREEN FOOD}

There are many advantages to establish documentary materials of the green food. The advantages are listed as following.

\subsection{Establishing Documentary Materials of the Green Food can Promote the Sustainable Development of the Green Food}

The growing unrest over food safety in China reached a climax in early 2007, shortly after circulation to the State Council of an Asian Development Bank policy note based on a technical assistance project in collaboration with the State Food and Drug Administration and the World Health Organization. The note and a subsequent report applauded increased efforts by the Chinese government but noted remaining gaps, calling in particular for urgent reforms to strengthen and streamline inter-agency coordination and enact an overarching "basic food law". The State Food and Drug Administration of China also published a survey in early 2007 where $65 \%$ of the respondents expressed concern about food safety. Shortly afterwards, Lu Jianzhong, a member of the National Committee of the Chinese People's Political Consultative Conference (CPPCC), and China's Vice Premier, $\mathrm{Wu} \mathrm{Yi}$, issued statements of apology and promised to create a food safety monitoring system.

In the year of 1992, Ministry of Agriculture launched Green Food Project and Heilongjiang took the lead in developing green food. After the 9 years development, Heilongjiang has become the most rapid province in developing green 
food all around the nation. Heilongjiang has established 4 national green food production bases and has 93 enterprises which produce green food and there are various kinds of products that use green food trademarks, accounts for $12.6 \%$ of the country. Among them, there are $121 \mathrm{~A}$ level and 7AA level, which accounts $12.2 \%$ and $25 \%$ of the country separately. There are 40 counties and 42 factory farms which produce green foods. There are about 20 hectares land that dedicated to produce green food, which accounts for $2 \%$ of the whole national arable land. In the year of 1998, the province green product production enterprise produce value of 1.75 billion yuan, the profit is 116 million yuan. These documentary materials provide accurate information for the enterprise that produce green foods, and promote the stable, healthy, rapid development of the green food.

\subsection{Establishing the Documentary Materials can Speed Up the Popularization of the Science and Technology And Innovation of Technology}

All works are indispensable from the documentary materials. Developing green food must hold on to the improvement of the technology. Through the accurate information, technological achievements in the documentary materials, that the special produce requirements in the green food can combine with the modern advanced scientific technologies.
The technological content in the green food production can be enhanced by improving technology innovation, strengthening the leading role that new technologies play in the process of production and manufacturing [8-10]. The documentary materials can supply technical support and abundant technical reserve for the healthy and rapid development of the green food. By using the modern technical devices and modern achievements of the research, the green food and related technologies can be put in the whole process of green food manufacturing.

\subsection{Establishing of the Documentary Materials of Green Food is the Fundamental Guarantee to the Protection and Improvement of Ecological Environment}

Favorable ecological environment is the basement and premise for the development and production of the green food. Strengthen the ecological consciousness is the fundamental measures to protect and improve the environment and development green food. Establishing the documentary materials and using documentary materials can make more and more people realize the importance of protecting and improving environment, and supervising and forcing people to improve environment in accordance with the law and leading the green food into legalized track. Establishing archivers of green food and making use of green food can make people

\begin{tabular}{|c|c|c|c|c|c|c|}
\hline Year & $\begin{array}{l}\text { Number of } \\
\text { enterprises }\end{array}$ & $\begin{array}{c}\text { Number of } \\
\text { products }\end{array}$ & $\begin{array}{c}\text { Annual sales } \\
\text { (109 yuan) }\end{array}$ & $\begin{array}{c}\text { Exports } \\
\left(10^{9} \text { yuan }\right)\end{array}$ & $\begin{array}{c}\text { Real yield } \\
\left(10^{4} \text { tons }\right)\end{array}$ & $\begin{array}{c}\text { Area of green food } \\
\left(10^{9} \text { acres }\right)\end{array}$ \\
\hline 1996 & 463 & 712 & 155.3 & 0.09 & 363.50 & 0.22 \\
\hline 1997 & 544 & 892 & 240.5 & 0.71 & 629.70 & 0.32 \\
\hline 1998 & 619 & 1018 & 285 & 0.88 & 840.60 & 0.34 \\
\hline 1999 & 742 & 353 & 302 & 1.30 & 1105.80 & 0.36 \\
\hline 2000 & 964 & 1831 & 400 & 2.00 & 1500 & 0.50 \\
\hline 2001 & 1217 & 2400 & 500 & 4.00 & 2000 & 0.58 \\
\hline 2002 & 1756 & 3046 & 597 & 8.40 & 2500 & 0.67 \\
\hline 2003 & 2047 & 4030 & 723 & 10.80 & 3260 & 0.77 \\
\hline 2004 & 2836 & 6496 & 860 & 12.50 & 4600 & 0.32 \\
\hline 2005 & 3695 & 9728 & 1030 & 16.20 & 6300 & 0.98 \\
\hline 2006 & 4615 & 12868 & 1500 & 19.60 & & 1.49 \\
\hline 2007 & 5740 & 15241 & 2066 & 21.50 & & 2.32 \\
\hline 2008 & 6176 & 17512 & 2597 & 23.20 & & 2.58 \\
\hline 2009 & 6003 & 15707 & 3162 & 21.60 & & 2.48 \\
\hline 2010 & 6391 & 16748 & 2823.8 & 23.10 & & 2.40 \\
\hline 2011 & 6622 & 16825 & 3134.5 & 23.00 & & 2.40 \\
\hline 2012 & 6862 & 17125 & 3178 & 28.40 & & 2.42 \\
\hline 2013 & 7696 & 19076 & 3625.2 & 26.00 & & \\
\hline tal increase & $17.98 \%$ & $21.34 \%$ & $20.36 \%$ & $39.56 \%$ & & \\
\hline
\end{tabular}

Data sources: China green food development center. The green food statistics annual report, author calcul ated.

Fig. (4). China green food overall situation 1996-2013.

\begin{tabular}{|c|c|c|c|c|c|}
\hline Year & $\begin{array}{l}\text { Number of green } \\
\text { food enterprises }\end{array}$ & Production $/ / 10^{4} \mathrm{t}$ & $\begin{array}{l}\text { Output value } \\
10^{8} \text { yuan }\end{array}$ & $\begin{array}{l}\text { Number of employees } \\
10^{4} \text { people }\end{array}$ & $\begin{array}{l}\text { Number of green } \\
\text { food certified }\end{array}$ \\
\hline 2005 & 274 & 458.4 & 164.5 & 6.6 & 900 \\
\hline 2006 & 294 & 539.7 & 182.3 & 7 & 1054 \\
\hline 2007 & 489 & 853.7 & 235.9 & 10.5 & 1200 \\
\hline 2008 & 492 & 950 & 232.6 & 13.2 & 1500 \\
\hline 2009 & 500 & 1000 & 241.4 & 14.9 & 1600 \\
\hline 2010 & 520 & 1050 & 260.1 & 15 & 1620 \\
\hline 2011 & 520 & - & 300.4 & 15.9 & 1700 \\
\hline
\end{tabular}

Fig. (5). Situation of development of green food enterprises in heilongjiang province. 
set up regulations and laws of green food in accordance with the current regulations and laws, and preventing the ecological environment be damaged by people effectively, establishing natural protection area of the green food and making the green food have a better environment [11].

\subsection{Establishing Archivers of Green Food can Strengthen the Awareness and Transparency of Green Food}

Green food refers to unpolluted, safe, high quality and nourished food. Through a great deal of documentary materials of green food can make use of various kinds of media to advertise green food extensively, especially some famous and high quality products with unique local characteristics, strengthen the reputation of the green food around the world, establish the whole image of the green food. Through archivers of green food can launch knowledge education of green food in a more broad way, constantly improve people's awareness of green food, hand the technologies of production of green food to the producers and promote the rapid and sustainable development of the green food.

\section{FOOD SAFETIES IN CHINA}

The growing unrest over food safety in China reached a climax in early 2007 , shortly after circulation to the State Council of an Asian Development Bank policy note based on a technical assistance project in collaboration with the State Food and Drug Administration and the World Health Organization. The note and a subsequent report applauded increased efforts by the Chinese government but noted remaining gaps, calling in particular for urgent reforms to strengthen and streamline inter-agency coordination and enact an overarching "basic food law". The State Food and Drug Administration of China also published a survey in early 2007 where $65 \%$ of the respondents expressed concern about food safety. Shortly afterwards, Lu Jianzhong, a member of the National Committee of the Chinese People's Political Consultative Conference (CPPCC), and China's Vice Premier, $\mathrm{Wu} \mathrm{Yi}$, issued statements of apology and promised to create a food safety monitoring system.

China's food regulations are complex, its monitoring system can be unresponsive, and the government departments that oversee and enforce policies have overlapping and often ambiguous duties. There are around ten national government departments that share the responsibility to ensure food safety. There are also numerous provincial and local agencies that monitor local food production and sales. The food and drug laws themselves have been created "in an ad hoc way without the benefit of a basic food law," as Henk Bekedam of the World Health Organization told the Wall Street Journal (9 April 2007, B1). The last major revision of the food and drug laws was made in 1995 when the Food Hygiene Law of the People's Republic of China established general food safety principles. Both the State Council and the departments under the State Council can issue regulations and directives concerning food.

Changes in China's food production system are generating an awareness of food safety problems. China's agricultural system is composed mostly of small land-holding farmers and subsistence agriculture. China, however, has less arable land than other nations and farmers intensively use fertilizer and pesticides to maintain high food production. Food is sold in both open air markets and urban supermarkets, and by the late 1990s, China's farms were adapting to more specialized crop production as the local markets become more connected to the national and international markets. However, local authorities largely control food regulation enforcement unless the central government steps in. As urban consumers' incomes increase, the demand for quality food goods, safer production, and processed foods also increases, and urban residents and supermarkets attract more national and media attention to food problems.

\section{CONCLUSION}

To increase consumers' trust in green food and promote the development of green food, regulatory authorities must strengthen the quality supervision work of the green food market, and creating a green food environment worthy of the public trust. First, it is necessary to prevent unsafe products from entering the market, prohibit the agricultural inputs with high degree of chemical fertilizer and pesticide residues, and implement quality safety access system in the production base and wholesale market. Second, green food testing organizations should implement strict annual inspection system for green food enterprises, and supervise the production, processing and sales process. Finally, the sampling results of the green food production should be timely released to the public through television, Internet and other media, and it is necessary to inform the public of the real situation of the enterprise and green food, to improve consumers' trust in green food and expand sales market.

\section{CONFLICT OF INTEREST}

The author confirms that this article content has no conflict of interest.

\section{ACKNOWLEDGEMENT}

This work is supported by the Key Project of Guangxi Social Sciences, China (No.gxsk201424), the Education Science fund of the Education Department of Guangxi, China (No.2014JGA268), and Guangxi Office for Education Sciences Planning, China (No.2013C108).

\section{REFERENCES}

[1] S. Baker, K.E. Thomspon, J. Engrlken, "Mapping the values driving organic food choice Germany vs the UK," European Journal of Marketing, vol. 8, no.38, pp. 995-1012, 2004.

[2] A.T. Bernardes, E.M. Albuquerque, "Cross-over, thresholds, and interactions between science and technology: lessons for lessdeveloped countries," Research Policy, vol. 32, no.5, pp.865-885, 2003.

[3] M. Brännback, and P. Wiklund, "A new dominant logic and its implications for knowledge management: a study of the Finnish food industry," Knowledge and Process Management, vol. 8, no.4, pp.197-206, 2001.

[4] M. Carriquiry, B.A. Babcock, "Reputations, market structure, and the choice of quality assurance systems in the food industry," American Journal of Agricultural Economics, vol. 89, no.1, pp. 1223, 2007. 
[5] Y. Liu, J.M. Zou, and X.H. Chen, "Study on countermeasures of green food industry development in Heilongjiang Province," Commercial Research, no.4, pp.107-111, 2010.

[6] K.J. Mao, "Study on the market risk of green food industry development in China," Zhejiang University, 2006.

[7] D.J. Song, and Y. Liu, "Study on export development strategy of Chinese pollution-free food based on DEA," Journal of Inner Mongolia Agricultural University, vol. 29, no.2, pp. 103-107, 2008.

[8] L. Squires, and B. Juric, "Level of market development and intensity of organic food consumption: cross-cultural study of Danish and New Zealand consumers," Journal of Consumer Marketing, vol. 18, no.5, pp. 392-409, 2001.
[9] Y.C. Zeng, W. Xia, and B. Huang, "Factors of consumers of green food purchasing and cognitive level and its influence based on the analysis of consumer survey in Beijing," Consumer Economics, vol. 23, no. 2, pp.38-42, 2007.

[10] D.W. Zhao, "The development upgrading and institutional advantages of green food industrial clusters in Heilongjiang province," Commercial Research, no. 9, pp. 204-206, 2008.

[11] D.W. Zhao, "Study on the growth stage of green food industry development and change," Academic Exchange, no.2, pp.55-58, 2009.

(C) Chong Zhang; Licensee Bentham Open.

This is an open access article licensed under the terms of the (https://creativecommons.org/licenses/by/4.0/legalcode), which permits unrestricted, noncommercial use, distribution and reproduction in any medium, provided the work is properly cited. 